\title{
Fibrin adhesive and the vaginal vault synthesis on female rabbits abdominal hysterectomies ${ }^{1}$
}

\author{
Adesivo de fibrina e a síntese da cúpula vaginal após histerectomia abdominal em coelhos fềmeas
}

\author{
Ari Gonçalves Lima', Murched Omar Taha ${ }^{\mathrm{II}}$, Henri Chaplin Rivoire ${ }^{\mathrm{III}}$, Anna Tereza Negrini Fagundes ${ }^{\mathrm{IV}}$, Djalma José Fagundes ${ }^{\mathrm{V}}$

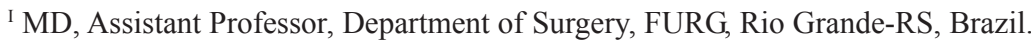 \\ ${ }^{\text {II }} \mathrm{PhD}$, Affiliate Professor, Surgical Techniques and Experimental Surgery Division, Department of Surgery, UNIFESP, Sao Paulo-SP, Brazil. \\ III PhD, Associate Professor, Head of Department of Surgery, FURG, Rio Grande-RS, Brazil. \\ Iv Graduate student, Santo Amaro University Medical School (UNISA), Sao Paulo-SP, Brazil. \\ v PhD, Associate Professor, Surgical Techniques and Experimental Surgery Division, Department of Surgery, UNIFESP, Sao Paulo-SP, Brazil.
}

\begin{abstract}
Purpose: To investigate the effectiveness of fibrin glue in comparison with polyglycolic acid suture to promote the closure of rabbit's vaginal vault, after abdominal hysterectomy. Methods: Twenty female, adults, New Zealand rabbits, were submitted to abdominal hysterectomy and randomly distributed to polyglycolic acid suture (G-PA / n=10) or fibrin glue closure of vaginal vault (G-FG / n=10). Radiograph study allowed identifying vault vaginal suture disrupter or fistulas to urinary bladder or rectum. Videovaginoscopy study allowed identifying the presence of cellulites, abscess formation, tissue granulation or granuloma. Vaginal cuff burst test allowed to identify by the escape of air bubbles and rupture pression record. Histological sections stained with Picrosirius red allowed the measure of fibrous tissue healing. Results: The videovaginoscopy identified a significant difference (Fisher Test $\mathrm{p}<0.3142$ ) of granulation tissue in the animals of G-PA (40\%) in comparison with the G-FG $(20 \%)$. The gross inspection showed the same relation in the granulation tissue occurrence (Fisher test $\mathrm{p}<0.1749)$ with G-PA $(50 \%)$ and G-FB $(20 \%)$. The visceral adhesion to the vaginal vault wound was statistical significant (Fisher test $\mathrm{p}<0.1749)$ with G-PA $(50 \%)$ and G-FG $(20 \%)$. The pressure of rupture $(\mathrm{mm} \mathrm{Hg})$ of the burst test was similar $(\mathrm{p}<0.0421)$ in the animals of G-PA $(61.5 \pm 19.3)$ and G-FG $(72.5 \pm 21.9)$. The collagen matrix of vault wound healing was similar $(\mathrm{p}<0.0231)$ between the G-PA $(31.63 \pm 15)$ and the G-FG (23.2 \pm 13.2$)$. Conclusion: The vaginal vault closure using the fibrin glue is a safe and reliable procedure after abdominal hysterectomy in female rabbit model.
\end{abstract}

Key words: Hysterectomy. Fibrin Tissue Adhesive. Vagina. Rabbits.

\section{RESUMO}

Objetivo: Investigar a eficácia da cola de fibrina e da sutura usando fio de ácido poliglicólico para promover o fechamento da cúpula vaginal de coelhas, após histerectomia abdominal. Métodos: Vinte coelhos fêmeas, New Zealand, adultas foram submetidas à histerectomia abdominal e distribuídas para sutura da cúpula vaginal com fio de ácido poliglicólico (G-PA/n=10) ou cola de fibrina (G-FG / n=10). Estudo radiológico foi realizado para identificar deiscências ou fístulas vesicais ou retais. Videovaginoscopia foi realizada para identificar a presença de secreções, abscessos, tecido de granulação ou granuloma tipo corpo estranho. Teste in vitro de pressão de rompimento sob selo d'água foi realizado para identificar a perviedade da sutura. O tecido de cicatrização foi estudado pela coloração com picrosirius red para mensuração do tecido fibrótico. Resultados: A videovaginoscopia mostrou uma diferença significante (Teste de Fisher p $<0,3142$ ) no tecido de granulação do grupo G-PA (40\%) em comparação com o grupo G-FG (20\%). A análise macroscópica mostrou a mesma relação com o tecido de granulação (Teste de Fisher p<0.1749) com G-PA $(50 \%)$ e G-FB (20\%). A aderência visceral à cúpula vaginal foi estatisticamente significativa (Teste de Fisher $\mathrm{p}<0.1749)$ com o G-PA $(50 \%)$ e G-FG (20\%). A pressão de rompimento (mmHg) foi similar $(\mathrm{p}<0.0421)$ nos animais do grupo G-PA $(61.5 \pm 19.3)$ e G-FG (72.5 21.9$)$. A matriz colagenosa do tecido de cicatrização teve resultados semelhantes $(p<0.0231)$ entre G-PA $(31.63 \pm 15)$ e G-FG (23.2 \pm 13.2$)$. Conclusão: O fechamento da cúpula vaginal usando cola de fibrina é um procedimento seguro e confiável após histerectomia abdominal em coelhos fêmeas.

Descritores: Histerectomia. Adesivo Tecidual de Fibrina. Vagina. Coelhos.

${ }^{1}$ Research performed at Surgical Technique Division, Department of Surgery, Rio Grande Federal University (FURG) and the Surgery and Experimentation Pos-Graduate Program, Operative Technique and Experimental Surgery Division, Department of Surgery, Federal University of São Paulo (UNIFESP), Brazil. 


\section{Introduction}

The hysterectomy is a wide surgical procedure and is performed in $20 \%$ to $30 \%$ of the women until the 6 th life decade. In United States of America about 600,000 hysterectomies were performed each year ${ }^{1,2}$. Ultimate Data-SUS (Public Health Service - Brazil) reported 65,569 hysterectomies in Brazil ${ }^{3}$.

Although, the mortality rate is around $3 \%$, the postoperative morbidity rate can reach $42.8 \%{ }^{4}$. Vaginal purulent ${ }^{5,6}$ or hemorrhagic discharge $\mathrm{e}^{7,8}$, perineal or lower abdominal pain ${ }^{9}$, urinary complains ${ }^{10}$, dyspareunia or postcoital spotting ${ }^{5,10}$ were frequently presents. These symptoms were associated to problems involving the vaginal cuff including bleeding ${ }^{9}$, haematoma ${ }^{7,11}$, cellulitis $^{9,12}$, abscess formation ${ }^{9}$, tissue granulation ${ }^{9,13}$, granuloma ${ }^{9,13}$ or visceral adhesions to vaginal vault ${ }^{14}$. These complications occurrence could be associated to the technique (open or a closed vaginal cuff) or to the type of vaginal cuff suture ${ }^{15}$.

Ideally, appropriate surgical management of the vaginal cuff should be technically simple, minimize risk of infection, dehiscence, and blood loss, and reduce frequency of delayed complications such as cuff tissue granulation ${ }^{16}$. The suture of vaginal cuff was associated to granulation tissue with plain catgut $(26 \%)$ or chromic catgut $(40 \%)$. The non-closure technique was associated to pelvic viscera adhesions $(47 \%)^{17}$.

Otherwise, the fibrin glue is a current biological surgical adhesive employed in several organs and tissues including in uterus and uterine tube ${ }^{18-21}$. It is used as a safe and reliable material on haemostatic and suture procedures. As human plasma derivate the fibrin provokes a mild and transitory inflammatory reaction and is completely absorbed in a few days. We hypothesized that the fibrin glue may achieve its beneficial effects on inflammatory healing of vaginal vault by impairment the granulation tissue formation and with the advantage of prevent further granuloma.

Thus, the aim of this study is to investigate the effectiveness of fibrin glue in comparison with polyglycolic acid suture to promote the closure of rabbit's vaginal vault, after abdominal hysterectomy, and to verify the inflammatory grade response.

\section{Methods}

The study protocol (\#971/00) was approved by the institutional Ethical Committee of São Paulo Federal University, São Paulo, Brazil. All procedures were in accordance to the rules of COBEA (Brazilian Committee of Animal Experimentation) and Guideline for the Care and Use of Laboratory Animals.

\section{Animals and groups}

Animals were housed and maintained in the animal facilities at the Rio Grande Federal University (FURG - RS - Brazil) according to appropriate guidelines. Twenty female, 8 months old, New Zealand albino rabbits, weight range from 3,850 t0 4,500g were randomly distributed in group polyglycolic acid suture (G-PA / $n=10)$ and group fibrin glue (G-FG / $n=10)$.

\section{Anesthetic procedure}

All the surgical proceedings were done under general anesthesia as the following standard protocol. After six hours fasting for solid diet and four hours for liquid diet, the animals received an intramuscular injection $(2 \mathrm{ml} / \mathrm{Kg})$ of anesthetics solution of zolazepam chloride $(125 \mathrm{mg})$ and tiletamina chloride $\left(125 \mathrm{mg}\right.$ ) in $5 \mathrm{ml}$ of distilled water (Zoletil ${ }^{\mathrm{TM}}$, Virbac Lab. - São Paulo- Brazil). The analgesia was providing by intramuscular injection $(0.05 \mathrm{mg} / \mathrm{Kg})$ of fentanile citrate (Fentanil ${ }^{\mathrm{TM}}$, Janssen Cilag Indústria Farmacêutica - São Paulo - Brazil). Just after the anesthesic induction a single intramuscular dose $(200 \mathrm{mg} / \mathrm{Kg})$ of sodium cephalotine (Laboratório Teuto Brasileiro - São Paulo Brazil).

\section{Surgical procedure of abdominal hysterectomy}

The animal was fixed in supine position and under aseptic condition was performed a median laparotomy. The both uterus horns were clamped and pull from the abdominal cavity to expose the right and left uterine vessels all of which were sutured and removed. The vaginal vault was now clamped and the uterus was resected by a scalpel incision $0.5 \mathrm{~mm}$ away from the superior edge of the clamp (Figure 1).

In the animals of group suture (G- PA) the borders of anterior and posterior layers of vaginal vault were closed by five interrupted suture of polyglicolic acid 3.0 (Figure 2).

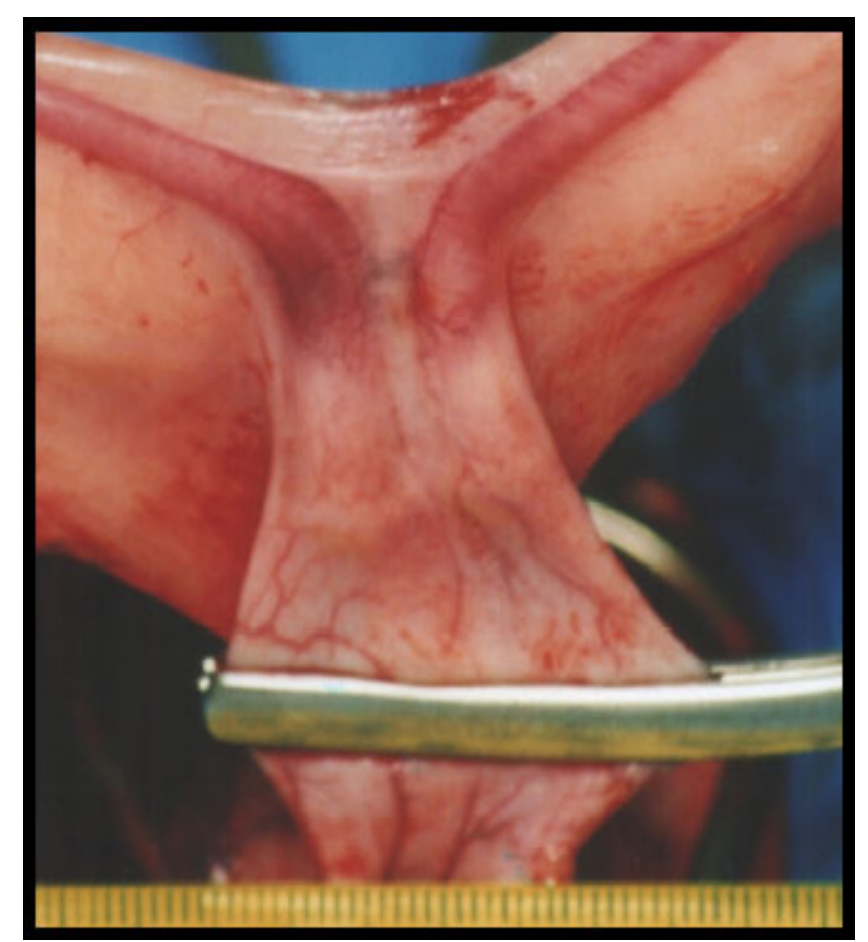

FIGURE 1 - The both uterus cornus pulled over and the clamp applied in the superior portion of vaginal vault 


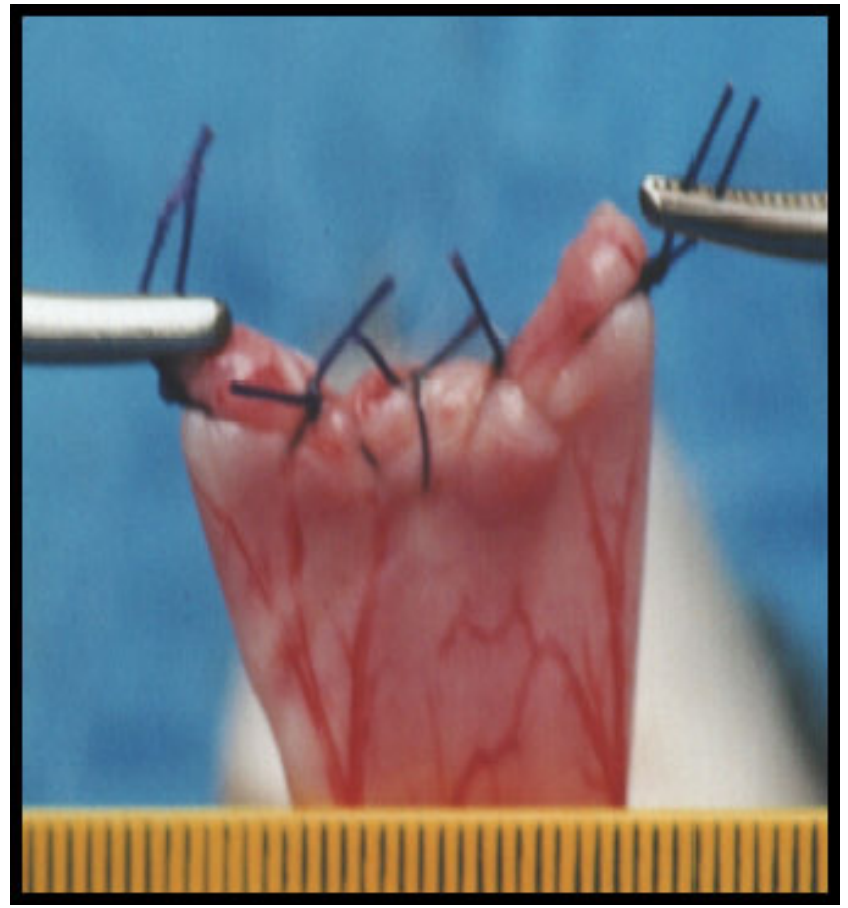

FIGURE 2 - The five interrupted polyglycolic acid 3.0 suture of the vaginal cuff

In the animals of group fibrin (G- FG) the borders of vaginal vault received a gently spread of $0.25 \mathrm{ml}$ of fibrin glue (TissucolTM $^{\mathrm{TM}}$ Baxter do Brasil - São Paulo - Brazil) that promote a slight adhesive layer between the anterior and posterior borders of vaginal vault. After seven minutes the clamp was removed (Figure 3). The muscle aponevrotic abdominal wall was closed by interrupted polyglycolic 3.0 sutures and the skin with a single row of nylon 4.0 suture.

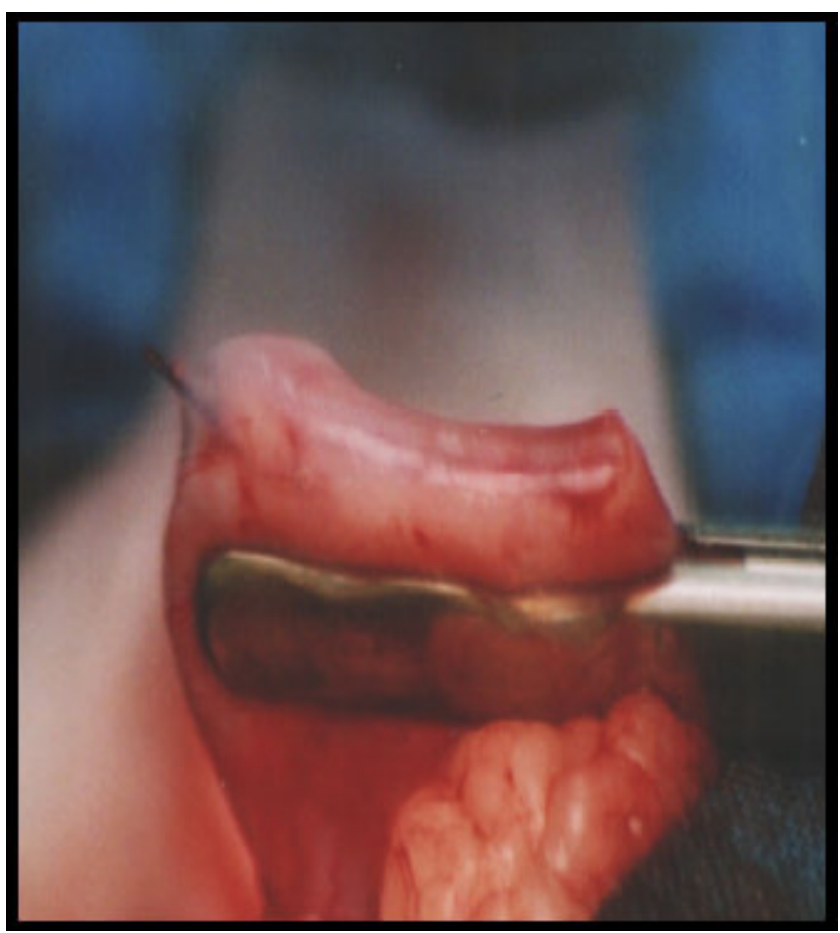

FIGURE 3 - The vaginal vault closed by the fibrin glue and immediately before the release of clamp

\section{Six weeks follow-up}

In the observation period it was recorded the occurrence of fever, incision infection or abscess, liquid stools or refuse of the chow or drinking water. Each five days the weight was controlled. Once any sign of severe suffering was identified, the Veterinary interrupted the research and the animals were sent to euthanasia.

\section{Radiograph study}

In the $45^{\text {th }}$ day, under anesthesia, the animals were submitted to a radiograph study (Siemens ${ }^{\mathrm{TM}}-$ Heliophos $4 \mathrm{~b}$ Com Image $-320 \mathrm{~mA}, 50 \mathrm{Kv}$ - Image intensifier). A Foley probe (10Fr) was introduced into the vaginal cavity and the ballonet was inflated with $5 \mathrm{ml}$ of distilled water and through the second channel was injected $5 \mathrm{ml}$ of radiopaque solution of $0.65 \mathrm{mg}$ of meglumine iodamine (Telebrix ${ }^{\mathrm{TM}}$ - Aspen Farmacêutica S/A - São Paulo - Brazil). The $0.0016 \mathrm{~s}$ exposure X-Ray plates allowed to identify vault vaginal suture disrupter or fistulas to urinary bladder or rectum.

\section{Videovaginoscopy study}

Videovaginoscopy was performed immediately after the radiograph study and using an Optical Storz ${ }^{\mathrm{TM}} 5 \mathrm{~mm} / 30$ o coupled to Microcamera Samsung ${ }^{\text {TM }}$ Digital Color CCs-212N, 300 watts Xenon Storz ${ }^{\mathrm{TM}}$ source, images capture and transmission by Telecan Storz $^{\mathrm{TM}}$ to Sony Color Monitor ${ }^{\mathrm{TM}}$. The vagina was distended with $8 \mathrm{ml}$ of saline solution and the vaginal vault was examined to identify the presence of, cellulites, abscess formation, tissue granulation or granuloma.

\section{Samples collected and euthanasia}

A U-shape incision on the abdominal wall allowed a safe access to the abdominal cavity and identification of eventual adhesions. After the abdominal gross inspection the entire vagina was gently resected. The euthanasia was performed by potassium chloride intravenous injection $(2 \mathrm{ml})$ until the cardio respiratory arrest.

\section{Vaginal cuff burst test}

The in vitro burst test was provided by introduction of a two-way Foley $15 \mathrm{Fr}$ probe that was tied in the vaginal ostium by the inflated ballonet. The second probe way was connected into a $\mathrm{Y}$ device. One branch was connected to $20 \mathrm{ml}$ syringe (used to injected air) and another branch was connected to manometer (Welch Allyn Tycos ${ }^{\mathrm{TM}}$ - USA) to measure the intravaginal pressure $(\mathrm{mm} \mathrm{Hg})$. The vagina was immersed in saline solution and progressive increase of pression was provided by air injection until the rupture of vault suture, identified by the escape of air bubbles. The rupture pression was recorded.

\section{Histological procedure}

The vagina specimens were fixed in $10 \%$ formalin solution, embedded in paraffin wax and $5 \mu \mathrm{m}$ sections were cut and stained with Picrosirius red. Three randomly histological cuts were made for all the groups along of the suture line. Histological 
evaluation was undertaken by an independent pathologist who had no knowledge of the experimental groups from which the specimens were derived. The images were captured through a high resolution camera from a CARL ZEISS Axilab $^{\mathrm{TM}}$ optic microscope. The software Image Pro Plus version 4.5 $5^{\mathrm{TM}}$ program (Media Cybernetics, Silver Spring, MD, USA) was used for analysis of morphometry data.

\section{Statistical analysis}

The statistical methodology represented the qualitative variables by absolute (n), relative (\%) frequency and the quantitative variables by means, standard deviation $(\mathrm{sd})$ and median. The 0.05 significance level $(\alpha \leq$ $5 \%$ ) was adopted and descriptive levels (p) lower than these values were considered significant.

\section{Results}

The surgical procedure time in G-PA was $22.8( \pm 3.4)$ minutes and 24.6( \pm 4.4$)$ minutes in the G-FG. It was no statistical significant (Fisher test $\mathrm{p}<0.023$ ).

The radiographic study showed the escape of radiopaque solution to the abdominal cavity forming a restricted space (less than $0.5 \mathrm{ml}$ ) in one animal of G-PA. This occurrence of $10 \%$ was no statistical significant.

The videovaginoscopy identified a significant difference (Fisher Test $\mathrm{p}<0.3142$ ) of granulation tissue in the animals of G-PA $(40 \%)$ in comparison with the G-FG $(20 \%)$. The gross inspection showed the same relation in the granulation tissue occurrence (Fisher test $\mathrm{p}<0.1749)$ with G-PA $(50 \%)$ and G-FB $(20 \%)$.

No abscess, cellulites or fistulas were identified in the videovaginoscopy or gross inspection.

The occurrence of visceral adhesions to the abdominal wall wound was similar in the two groups with no statistical difference (Fisher test $\mathrm{p}<0.50)$ with G-PA $(30 \%)$ and G-FG (20\%). On the other hand, the visceral adhesion to the vaginal vault wound was statistical significant (Fisher test $\mathrm{p}<0.1749$ ) with g-PA (50\%) and G-FG (20\%).

The in vitro burst test (Figure 4) showed no statistical differences $(\mathrm{p}<0.0421)$ in the animals of G-PA $(61.5 \pm 19.3)$ and G-FG (72.5 \pm 21.9$)$.

The collagen matrix of vault wound healing (Figure 5) was similar $(\mathrm{p}<0.0231)$ between the G-PA $(31.63 \pm 15)$ and the G-FG (23.2 \pm 13.2$)$.

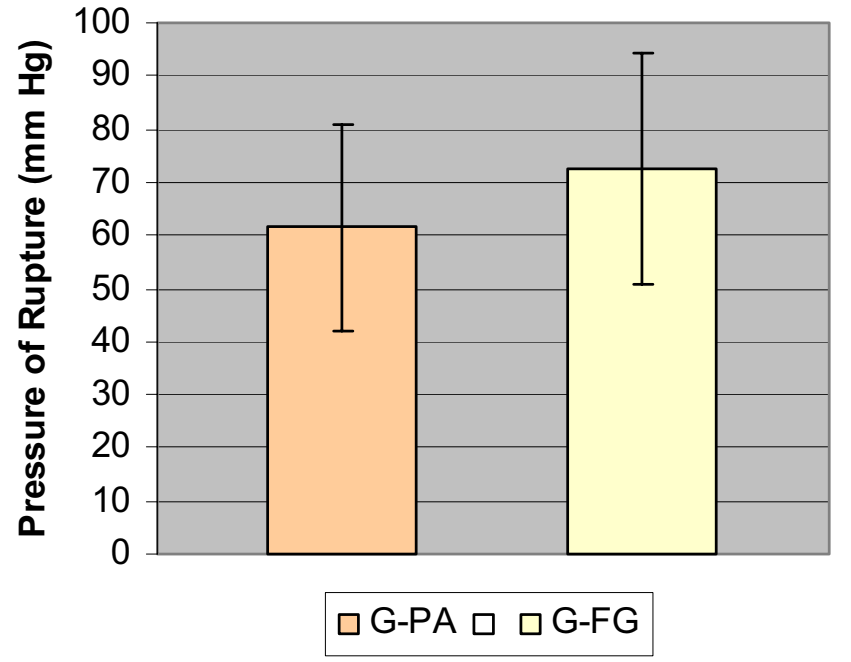

FIGURE 4 - Results of the of the in vitro the burst test (expressed in $\mathrm{mm} \mathrm{Hg}$ )

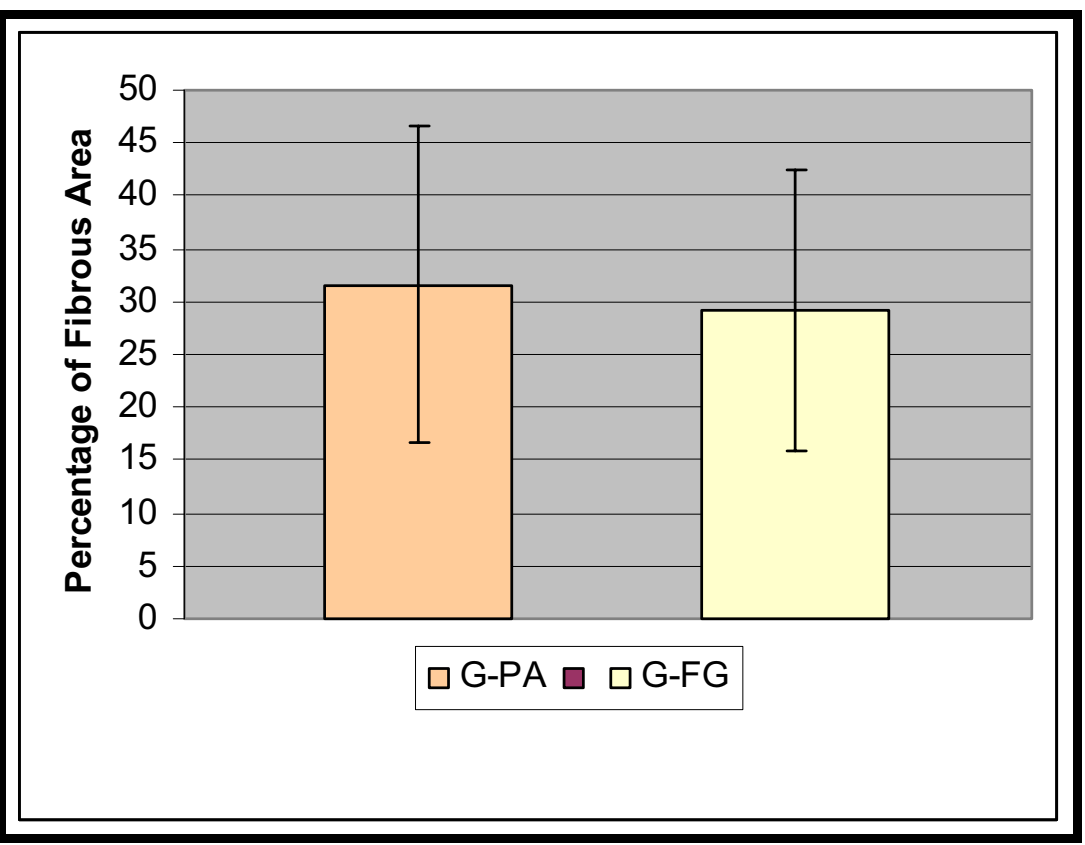

FIGURE 5 - Results of the collagen matrix (percentage of picrosirius red expression) of vault wound healing

\section{Discussion}

A brief review in the last six years in attention to surgical management of vaginal vault after total abdominal hysterectomy showed only reports in human being ${ }^{5-15}$. All of them stand up the relations of the surgical techniques of vault closure to post operative complains. No reports were identified using an animal model.

The main problem was related to two surgical procedures: open or closure of the vaginal vault. The rates of vaginal discharge $\mathrm{e}^{5-8}$, haematomas ${ }^{7,11}$, sexual dysfunction ${ }^{5,10}$, visceral adhesions ${ }^{14,16}$, fever and infections ${ }^{9}$, vault vaginal granulation ${ }^{9,13,14,16}$ were discussed and different improvements on surgical techniques were proposal. 
The different patient samples and suture materials as the correlated procedures act as limiting factor to a made a consensus.

We proposed an animal model hereby that intend to promote a standard model that allows a rational and controlled of the multiple variables involved. For the initial purpose a comparison of two closure procedure was tested.

The total abdominal hysterectomy with vaginal vault closure is more frequently reported than the open vault technique ${ }^{15,17}$, probably due to longer operation time of open procedure. This longer operation time for the open vault technique stems from the need for both peritoneal cover and haemostatic sutures around the vaginal cuff. In the present study, in both groups, the peritoneum was not sutured and no significant differences (Fisher test $\mathrm{p}<0.023$ ) on the operation time was noted with suture or adhesive, although the fibrin glue required about seven minutes for the total polymerization. The haemostatic and adhesive properties of fibrin allowed to prevent the hemorrhagic loss and at same time promote the closure of vault edges.

In the closed vault procedure the pelvic fluid collection is probably the result of a mixture of blood, lymphatic and serous fluid and necrotic debris that collects around the vaginal vault $t^{15,22}$. The organic reaction to the material of suture and the ischemia promote by continue or interrupted suture should be responsible by the main rate of necrosis debris. Thus, the surgical adhesive such the fibrin glue could be an effective procedure in to promote the vault closure with less necrosis in the same time that promotes the hemostasia. The results of videovaginoscopy and gross inspection confirmed the less granulation tissue and inflammatory reaction in the animals of fibrin glue closure.

The collection rate was reported as a range from 34 to $66 \%$ for the closed operation and $40 \%$ for the open cuff procedure and the infection rates was high in the open procedure ${ }^{23,24}$. The absent of abscess, cellulites or fistulas on both groups comproved the adequacy of the animal model and the performance of surgical technique. Only one animal from the suture group showed a fistula with little collection of radiopaque solution on the right side of vaginal vault.

The visceral adhesion to the abdominal wound was similar to both groups, but the adhesions to the vaginal vault were significantly high in the suture group. The fibrin is a biological derivate and associated to a less inflammatory reaction on all other tissue where was used. This should be the key role in the less adhesions formation.

As was stated before, in the last six years there were no reports of animal model for uterine vault closure. The animal model describe herein seemed feasible and relevant for further studies. At least, these results suggested that the fibrin was effectiveness into promote a vaginal vault closure with less occurrence of vaginal discharge, less granulation tissue and with the similar resistance of an interrupted polyglycolic suture. The procedure could be considered as an experimental procedure for further research on closure of women uterine vault, mainly in vaginal hysterectomy.

\section{Conclusion}

The vaginal vault closure using the fibrin glue is a safe and reliable procedure after abdominal hysterectomy in female rabbit model.

\section{References}

1. Kovac SR, Barthan S, Lister M, Tucker L, Bishop M, Das A. Guidelines for the selection of the route of hysterectomy: application in a resident clinic population. Am J Obstet Gynecol. 2002;187(6):1521-7.

2. Davies A, Hart R, Magos A, Hadad E, Morris R. Hysterectomy: surgical route and complications. Eur J Obstet Gynecol Reprod Biol. 2002;104(2):148-51.

3. Ministério da Saúde. Procedimentos hospitalares do SUS. Available in http://www.datasus.gov.br/cgi/sih/pimap.htm (access in jun/25/2008).

4. McDonald TW. Hysterectomy: indications types and alternatives. In: Copeland LJ. Textbook of gynecology. 5ed. Philadelphia: Saunders; 1993. p.779-801.

5. Krogh RA, Rasmussen KL. Vaginal vault fluid collection after hysterectomy: frequency and clinical significance. Ugeskr Laeger. 2006;168(19):1867-70.

6. Janschek EC, Hohlagschwandtner M, Nather A, Schindl M, Joura EA. A study of non-closure of the peritoneum at vaginal hysterectomy. Arch Gynecol Obstet. 2003;267(4):213-6.

7. Morris EP, El-Toukhy T, Toozs-Hobson P, Hefni MA. Refining surgical technique to prevent occurrence of vault haematoma after vaginal hysterectomy. J Obstet Gynaecol. 2001;21(4):379-82.

8. Malinowski A, Molas J, Maciolek-Blewniewska G, Cieslak J. The modification in surgical technique of incision and closure vault of the vagina during vaginal hysterectomy on the incidence of vault haematoma. Ginekol Pol. 2006;77(2):117-25.

9. Shen CC, Hsu TY, Huang FJ, Roan CJ, Weng HH, Chang HW, Chang SY. Comparison of one and two layer vaginal cuff closure and open vaginal cuff during laparoscopic-assisted vaginal hysterectomy. J Am Assoc Gynecol Laparosc. 2002;9(4):474-80.

10. Tunuguntla HS, Gousse AE. Female sexual dysfunction following vaginal surgery: a review. J Urol. 2006;175(2):439-46.

11. Miskry T, Magos A. Mass closure: a new technique for closure of the vaginal vault at vaginal hysterectomy. BJOG. 2001;108(12):1295-7.

12. Watrowski R, Friebe Z. Contemporary views on perioperative complications and adhaesion formation after vaginal hysterectomy, in relation to peritoneal closure vs. non-closure in combination with open vs. closed vaginal cuff. Ginekol Pol. 2006;77(12):973-9.

13. Tannirandorn Y, Tuchinda K. Vaginal vault granulations after total abdominal hysterectomy using polyglactin for vault closure. J Med Assoc Thai. 2001;84(5):693-6.

14. Al-Sunaidi M, Tulandi T. Adhesion-related bowel obstruction after hysterectomy for benign conditions. Obstet Gynecol. 2006;108(5):1162-6.

15. Aharoni A, Kaner E, Levitan Z, Condrea A, Degani S, Ohel G. Prospective randomized comparison between an open and closed vaginal cuff in abdominal hysterectomy. Int J Gynaecol Obstet. 1998;63(1):29-32. 16 Shen CC, Lu HM, Chang HY. Characteristics and management of large bowel injury in laparoscopic-assisted vaginal hysterectomy. J Am Assoc Gynecol Laparosc. 2002;9(1):35-9.

17. Manyonda IT, Welch CR, Macwiney NA. The influence of suture material on vaginal vault granulation following abdominal hysterectomy. Br J Obstet Gynaecol. 1990;97:608-12.

18. Dunn CG, Goa KC. Fibrin sealant: a review of its use in surgery and endoscopy. Drugs. 1999;98:863-86.

19. Rivoire HC, Fagundes DJ, Taha MO, Novo NF, Juliano Y. Esterilização tubária com adesivo cirúrgico sintético: estudo experimental. Rev Col Bras Cir. 2003;30:337-43.

20. Bigolin S, Fagundes DJ, Rivoire HC, Fagundes ATN, Simões R, Simões MJ. Hysteroscopic sterilization with occlusion of sheep uterine tube using n-butyl-2-cyanoacrylate adhesive patch. Acta Cir Bras. 2007;22(5):401-6.

21. Rivoire HC, Fagundes DJ. Surgical adhesives and tubal sterilization: an experimental study. J Obstet Gynaecol Res. 2008;34:218-27. 
22. Toglia MR, Pearlman MD. Pelvic fluid collections following hysterectomy and their relation to febrile morbidity. Obstet Gynecol. 1994;83:766-70.

23. Slavotinek J, Berman L, Burch D, Keefe B. The incidence and significance of acute post-hysterectomy pelvic collections. Clin Radiol. 1995;50:322-6.

24. Haines CJ, Shan YO, Hung TW, Chung TK, Leung DH. Sonographic assessment of the vaginal vault following hysterectomy. Acta Obstet Gynecol Scand. 1995;74:220-3.

Conflict of interest: none Financial source: CAPES

\section{Correspondence:}

Henri Chaplin Rivoire

Rua Barão de Cotegipe, 682

96200290 Rio Grande - RS Brazil

Phone: (55 53)3232-6322

henri@mikrus.com.br

Received: August 11, 2008

Review: October 14, 2008

Accepted: November 18, 2008

\section{How to cite this article}

Lima AG, Taha MO, Rivoire HC, Fagundes ATN, Fagundes DJ. Fibrin adhesive and the vaginal vault synthesis on female rabbits abdominal hysterectomies. Acta Cir Bras. [serial on the Internet] 2009 Jan-Feb;24(1). Available from URL: http://www.scielo.br/acb 